\title{
Development of Glassy Carbon Electrode Modified with Ruthenium Red-multiwalled Carbon Nanotubes for Simultaneous Determination of Epinephrine and Acetaminophen
}

\author{
Hadi Hassani Nadiki, Meissam NoroozifaR ${ }^{\dagger}$, and Mozhgan Khorasani-Motlagh \\ Department of Chemistry, University of Sistan and Baluchestan, Zahedan, Iran
}

\begin{abstract}
A glassy carbon electrode modified with ruthenium red and functionalized multi-walled carbon nanotube has been developed. The electrochemical response characteristics of the modified electrode toward epinephrine (EP) and acetaminophen (AC) was investigated by differential pulse voltammetry (DPV). Linear calibration plots were obtained over the range of $0.3-333.3 \mu \mathrm{M}$ for both $\mathrm{EP}$ and $\mathrm{AC}$ with sensitivities of 0.221 and $0.174 \mu \mathrm{A} \mu \mathrm{M}^{-1}$ for $\mathrm{EP}$ and $\mathrm{AC}$, respectively. The detection limits for $\mathrm{EP}$ and $\mathrm{AC}$ were 0.04 and $0.06 \mu \mathrm{M}$, respectively. The diffusion coefficients for the oxidation of EP and $\mathrm{AC}$ at the modified electrode were calculated as $2.74 \pm 0.05 \times 10^{-5}$ and $1.75 \pm 0.07 \times 10^{-5} \mathrm{~cm}^{2} \mathrm{~s}^{-1}$, respectively. The practical analytical utilities of the modified electrode were demonstrated by the determination of EP and $\mathrm{AC}$ in human urine and serum as well as $\mathrm{AC}$ tablet samples.
\end{abstract}

Keywords Sensor, ruthenium red, carbon nanotubes, epinephrine, acetaminophen

(Received May 1, 2014; Accepted July 3, 2014; Published September 10, 2014)

\section{Introduction}

Catecholamines are a class of monoamines that serve as neurotransmitter compounds in the mammalian central nervous system. They are hormones that are released by the adrenal glands in situations of psychological stress or low blood sugar levels. ${ }^{1,2}$ Epinephrine (EP), also known as adrenaline, plays an important role during mental stress and stimulates a series of actions of the sympathetic nervous system called "fight or flight response". EP concentration in blood affects regulation of blood pressure heart rate, lipolysis, immune system and glycogen metabolism., ${ }^{3,4}$ From the point of view of medicine, it is a drug for emergency treatment in severe allergic reactions, cardiac arrest and sepsis. ${ }^{5}$ Many methods have been described for the determination of EP, such as chromatographic methods, ${ }^{6-8}$ capillary electrophoresis. ${ }^{9}{ }^{10}$ flow injection, ${ }^{11}$ chemiluminescence, ${ }^{12}$ fluorimetry ${ }^{13}$ and spectrophotometry. ${ }^{14,15}$ Many of modified GC electrodes have been used for the electrochemical determination of EP; they include with poly caffeic acid electrode, ${ }^{16}$ poly(eriochrome Black T), ${ }^{17}$ polyrutin, ${ }^{18}$ poly(taurine) ${ }^{19}$ and modified carbon paste electrode with pre-anodized inlaying ultrathin with nichrome,$^{20}$ 2,2-[1,2-ethanediylbis(nitriloethylidyne)]bis-hydroquinone double-wall carbon nanotube, ${ }^{21}$ as well as modified gold electrode with 2-(2,3-dihydroxy phenyl)-1,3dithiane self-assembled monolayer. ${ }^{22}$

Acetaminophen (AC) is a popular, non-carcinogenic and widely used analgesic and antipyretic medicine with rather limited anti-inflammatory properties. ${ }^{23}$ It is an effective substitute for acetylsalicylic acid for patients who cannot

† To whom correspondence should be addressed.

E-mail: mnoroozifar@chem.usb.ac.ir tolerate acetylsalicylic acid. The normal concentration range of acetaminophen for therapeutic purposes can be affected by gender, age, general health, synergism with other compounds, and individual response. The plasma concentration of acetaminophen in humans follows a standard drug dose in the range from 50 to $100 \mu \mathrm{M}^{24,25}$ However, overdosing of $\mathrm{AC}$ can produce toxic metabolite accumulation which can causes kidney and liver damage. ${ }^{26}$ Thus, the development of efficient, sensitive, and simple analytical techniques for the determination of acetaminophen are important. Several methods such as chromatography, ${ }^{27,28}$ spectrophotometry, ${ }^{29-31}$ fluorimetry, ${ }^{32}$ flow injection $^{33,34}$ and voltammetry ${ }^{35}$ have been developed to determine $\mathrm{AC}$ in pharmaceutical and clinical samples. But, these methods have several disadvantages such as long analysis time, high costs and requirement for sample pretreatment that is time consuming, making them unsuitable for routine analysis. Among these methods, voltammetry methods are highly sensitive, selective, measure over a wide linear range, require no sample preparation and are thus less time consuming for the determination of AC. So, a number of modified electrodes have been used for the electrochemical detection of $\mathrm{AC},{ }^{36-41}$ for example, carbon-coated nickel magnetic nanoparticles modified electrode $^{40}$ and $\mathrm{Cu}(\mathrm{II})$-conducting polymer complex modified electrode. ${ }^{41}$

A polycationic dye called ammoniated ruthenium oxychloride, also known as ruthenium red (RR), is an inorganic dye. It is used in histology to stain aldehyde fixed mucopolysaccharides. It is a pharmacological tool to study specific cellular mechanisms. Selectivity is a significant issue in such studies as RR is known to interact with a large number of proteins. ${ }^{42}$ It is a potent inhibitor of intracellular calcium released by Ryanodine receptors ${ }^{43}$ and displays nanomolar potency against several of its binding partners such as TRPV4, Ryanodine receptors. RR has 


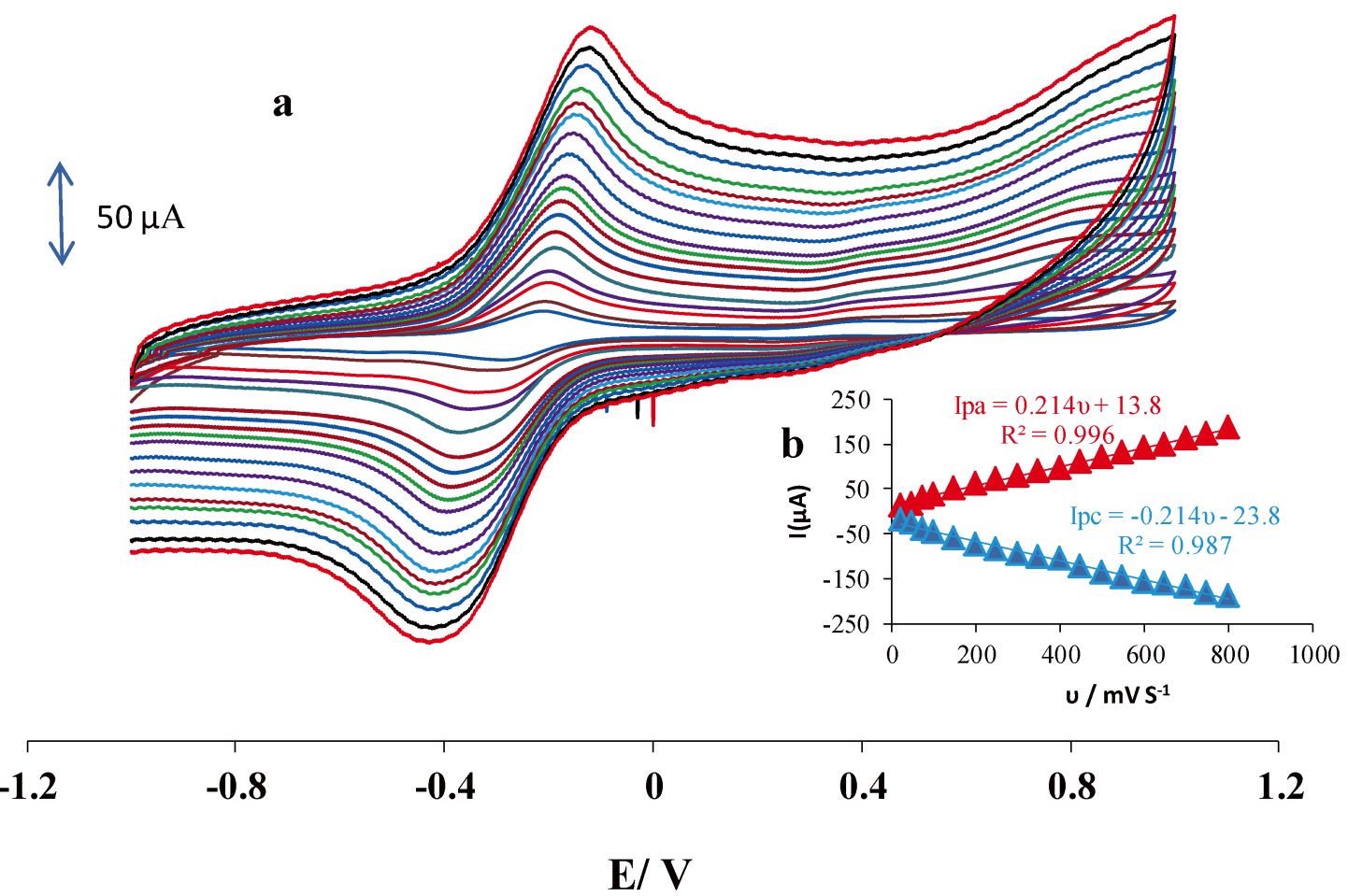

Fig. 1 a. CVs of NF-RR-CNTs/GC electrode in AABS with pH 5.5 at various scan rates (from inner to outer curve): $25,50,75,100,150,200,250,300,350,400,450,500,550,600,650,700,750$ and $800 \mathrm{mV} \mathrm{s}^{-1}$. b. The plot of peak currents $v s$. scan rates.

been used just one time for the determination of L-DOPA using a modified electrode with RR supported on Y-type zeolite. ${ }^{44}$

To the best of our knowledge, no study has been reported on the electroanalysis and simultaneous determination of EP and AC using a modified GC electrode by functionalized multiwalled carbon nanotubes (CNTs)-RR nanocomposite. This paper includes the simple method for preparation of a new modified GC electrode based on CNTs-RR dispersed in Nafion (NF) for the simultaneous determination of EP and AC. Low detection limits and high sensitivity for these two species were obtained due to the high electrocatalytic properties of CNTs-RR. The analytical performance of this sensor was evaluated for simultaneous determination of EP and AC by differential pulse voltammetry. Finally, this sensor has been used for the successful determination of these compounds in AC tablets, human serum and urine samples.

\section{Experimental}

\section{Reagents and solutions}

$\mathrm{EP}, \mathrm{AC}$, phenylalanine, L-cysteine, tyrosine, metionine, folic acid, glucose, atropine and asparagines were purchased from Sigma-Aldrich and used as received. Aqueous solutions were prepared with doubly distilled water (DDW). Solutions of $1.0 \times 10^{-3} \mathrm{~mol} \mathrm{~L}^{-1} \mathrm{EP}$ and $\mathrm{AC}$ were prepared daily by dissolving an appropriate amount of EP and AC in DDW. The solutions were kept in a refrigerator in the dark. The inorganic dye ammoniated ruthenium oxychloride, which is a polycationic dye also known as RR was purchased from Merck. Nafion (5\%) (NF) was purchased from Aldrich. Multi-walled carbon nanotubes with nanotube, o.d. $=20-30 \mathrm{~nm}$, wall thickness $=$ $1-2 \mathrm{~nm}$, length $=0.5-2 \mu \mathrm{m}$ and purity of $>95 \%$ was purchased from Aldrich. Dichloroacetic acid, chloroacetic acid and acetic acid were purchased from May \& Bayker and Merck Co. Dichloroacetic acid $\left(\mathrm{p} K_{\mathrm{a}}=1.26\right)$ was used for the preparation of buffer solutions between $\mathrm{pH} 1.0$ and 1.8; it was prepared by adjusting it to the desire $\mathrm{pH}$ with $0.1 \mathrm{~mol} \mathrm{~L}^{-1} \mathrm{NaOH}$ solution. In the same way, chloroacetic acid $\left(\mathrm{p} K_{\mathrm{a}}=2.87\right)$ for $\mathrm{pH}$ between 1.8 and 3.8 and acetic acid $\left(\mathrm{p} K_{\mathrm{a}}=4.76\right)$ for $\mathrm{pH}$ between 3.8 and 5.6 were used.

AC was obtained from Kharazmi (325 mg tablets, Kharazmi Pharmaceutical Co., Tehran, Iran). Fresh human urine and serum samples were obtained from Omid Clinical Laboratory (Zahedan, Iran). Serum and urine samples were filtered and diluted 2.0 times using a $0.1 \mathrm{~mol} \mathrm{~L}^{-1}$ acetic acid buffer solution (AABS) of $\mathrm{pH} 5.5$ and checked for the determination of the recovery after spiking of $\mathrm{EP}$ and $\mathrm{AC}$.

\section{Apparatus}

Electrochemical measurements were performed with an SAMA500 Electroanalyser (SAMA Research Center, Iran) controlled by a personal computer. The three-electrode cell system consisted of a glassy carbon working electrode (GCE, modified or unmodified), a saturated calomel electrode (SCE) as reference electrode and a Pt wire electrode as the auxiliary electrode. All the electrochemical experiments were carried out under a pure nitrogen atmosphere at room temperature.

\section{Preparation of the modified electrode}

Multi-walled carbon nanotubes were first subjected to the oxidative pretreatment by vigorously stirring in a mixture of concentrated sulfuric acid and nitric acid at a volumetric ratio of $3: 1$ at room temperature for $24 \mathrm{~h}$. This pretreatment removes impurities and generates sufficient functional groups on the surface of CNTs. ${ }^{45}$ The treated CNTs were separated by 

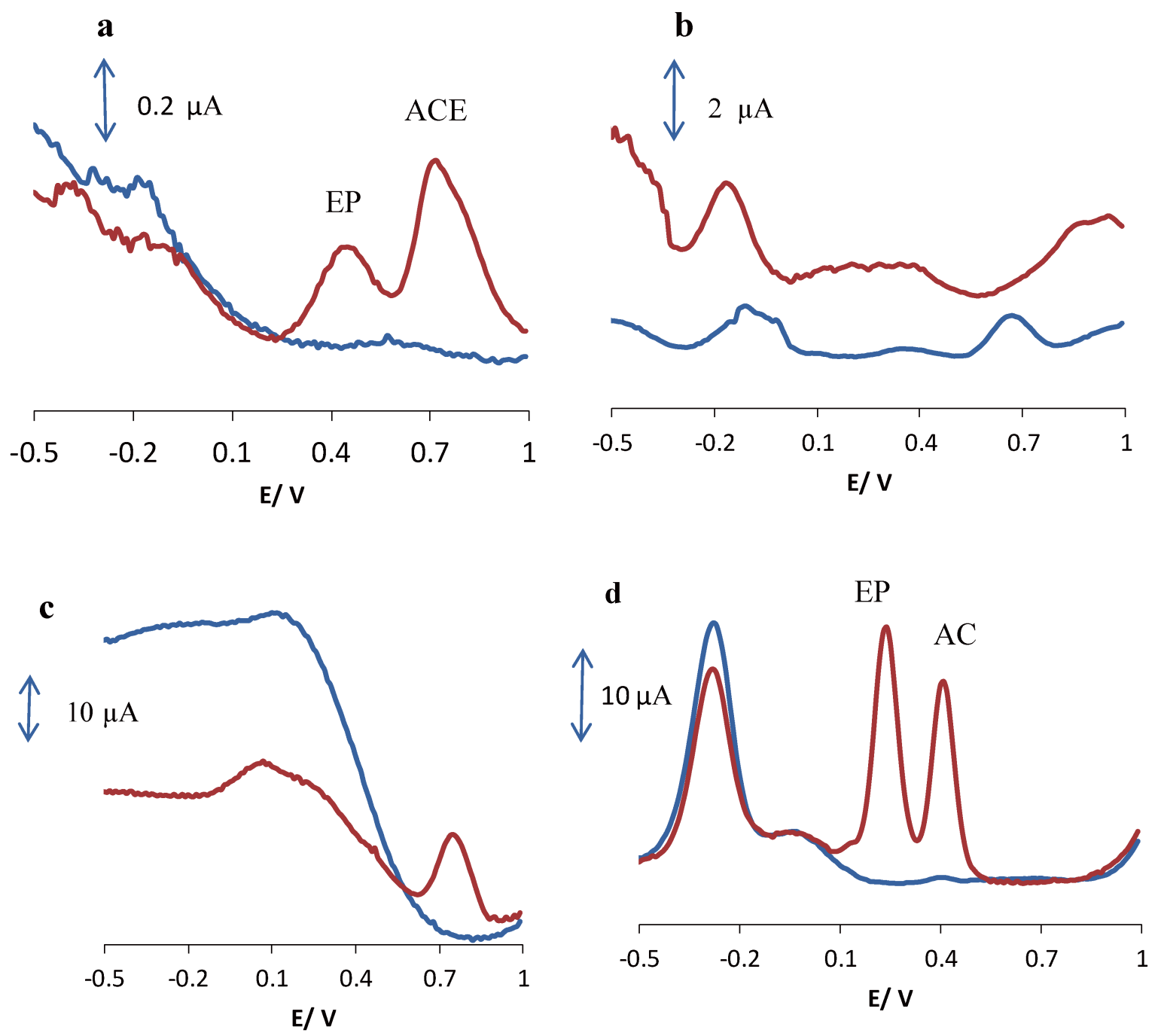

Fig. 2 a. DPV at BGCE, b. NF-RR/GC, c. NF-CNTs/GC, d. NF-RR-CNTs/GC electrodes in the presence of $\mathrm{EP}$ and $\mathrm{AC}(126.6 \mu \mathrm{M}$ each $)$ in $\mathrm{AABS}(0.1 \mathrm{M})$ at $\mathrm{pH} 5.5$.

centrifugation (2000 rpm) and washed with DDW until the $\mathrm{pH}$ of the filtrate reached 7.0. After further washing and drying, $25 \mathrm{mg}$ of CNTs was sonicated in $1.0 \mathrm{~mL}$ of $\mathrm{RR}$ solution $\left(4 \times 10^{-3} \mathrm{~mol} \mathrm{~L}^{-1}\right)$ and $50 \mu \mathrm{L} \mathrm{NF}(5 \%)$ for $2 \mathrm{~h}$. This mixture was denoted as NF-RR-CNTs and used for electrode modification.

The GC electrode with $0.0314 \mathrm{~cm}^{2}$ surface area was polished with $0.05 \mu \mathrm{m}$ alumina slurry to a mirror finish surface and then rinsed with DDW. The GC electrode was subsequently sonicated in a mixture of water:ethanol $(9: 1 \mathrm{v} / \mathrm{v})$ for $3 \mathrm{~min}$. The GC electrode was cleaned and activated in an electrochemical cell containing $1.0 \mathrm{M}$ of deoxygenated $\mathrm{H}_{2} \mathrm{SO}_{4}$ by using cyclic voltammetry between -1.5 and $+1.5 \mathrm{~V}$ at a scan rate of $100 \mathrm{mV} / \mathrm{s}$ until a stable cyclic voltammetric profile $(\approx 15$ times $)$ was obtained. The clean GC electrode was coated by casting $5.0 \mu \mathrm{L}$ of the NF-RR-CNTs suspension and then put the electrode under infrared radiation for fast drying. This modified GC electrode was denoted as NF-RR-CNTs/GC. When not in use, the modified electrode was stored in DDW. The NF-CNTs/GC and NF-RR/GC were also prepared with the same method.

\section{Results and Discussion}

\section{Electrochemical properties of NF-RR-CNTs/GC}

Figure 1a displays the CVs of NF-RR-CNTs/GC in acetic acid buffer solution (AABS) with $\mathrm{pH}=5.5$ at different scan rates. A pair of reduction and oxidation peaks at -0.193 and $-0.36 \mathrm{~V}$ with peak potential separation $\Delta E_{\mathrm{p}}=-0.17 \mathrm{~V}$ was obtained. Figure $1 \mathrm{~b}$ shows the voltammetric peaks potential of NF-RR$\mathrm{CNTs} / \mathrm{GC}$ at scan rates ranging from 25 to $800 \mathrm{mV} \mathrm{s}^{-1}$. There is a linear variation between peak current and scan rate $(v)$ (Fig. 1b) with the regression equation $I_{\mathrm{pa}}(\mu \mathrm{A})=0.214 v+13.76$ (correlation coefficient, $r=0.9979)$ and $I_{\mathrm{pc}}(\mu \mathrm{A})=-0.214 \mathrm{v}-$ $23.84(r=0.9934)$, indicating surface-controlled electrode processes. As shown in Fig. $1 \mathrm{~b}, I_{\mathrm{pa}}$ and $I_{\mathrm{pc}}$ were linearly dependent on the scan rate as expected for a surface confinedredox process. These behaviors are consistent with a diffusionless system, a reversible electron-transfer process at low scan rates. The corresponding reactions of these voltammograms can be attributed to redox reaction of RR

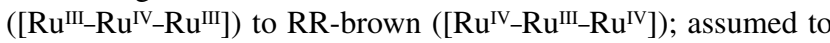
be a one-electron transfer: ${ }^{46}$ 

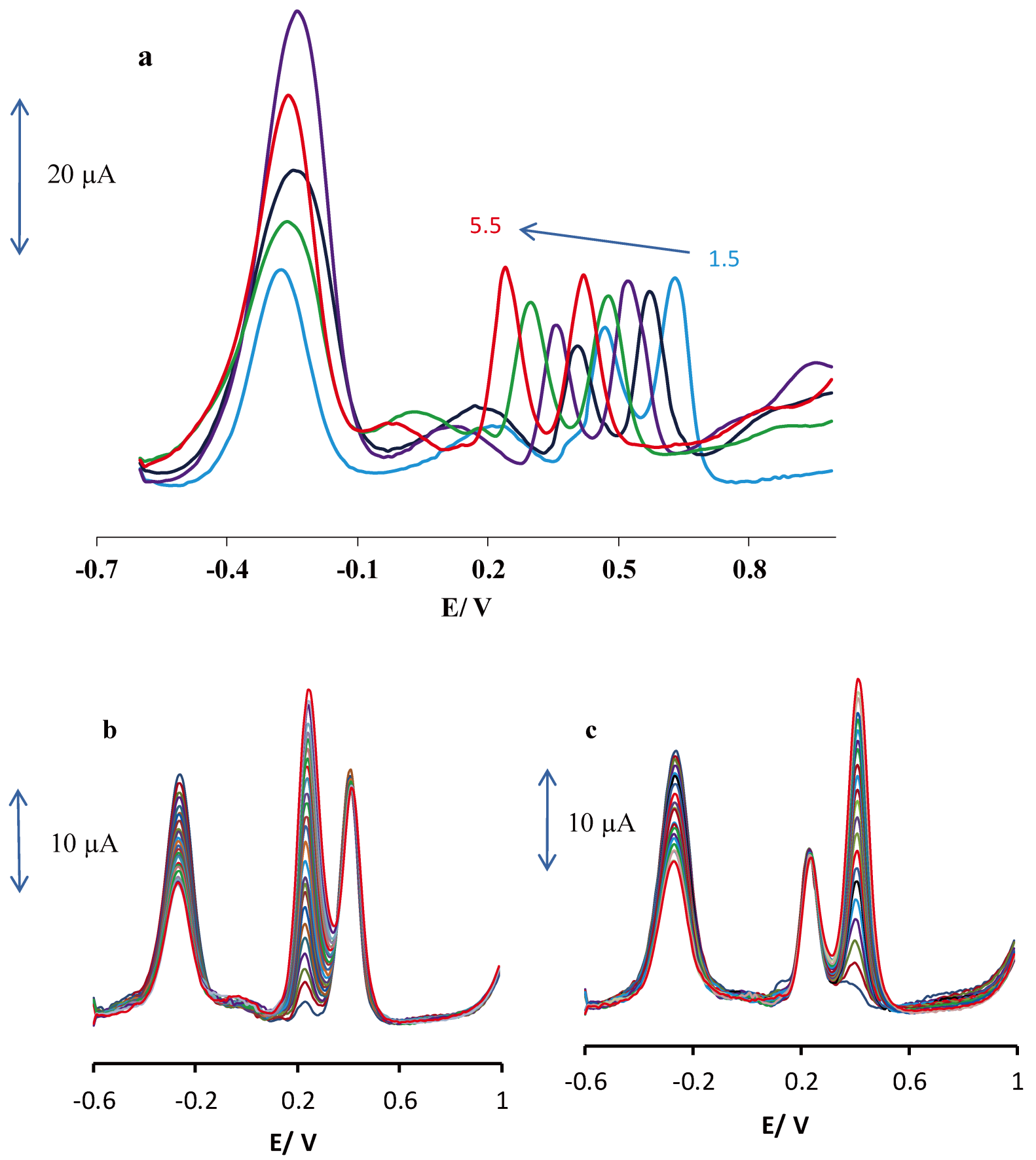

Fig. 3 a. Effect of $\mathrm{pH}$ on the peak separation and peak current for the oxidation of AC, and EP $(133.3 \mu \mathrm{M})$ at the NF-RR-CNTs/GC electrode; $\mathrm{pH}=1.5-5.5$. DPV at the NF-RR-CNTs/GC electrode for interference study of AC and EP, b. containing AC $(200.0 \mu \mathrm{M}$ and different concentrations of EP (from inner to outer): $\mathrm{EP}(6.6,13.3,20.0,26.6,33.3,40.0,46.6,53.3,60.0,66.6,100.0,116.6,133.3$, $150.0,166.6,183.3,200.0,216.6,233.3,250.0,266.6,283.3,300.0,316.6,333.3)$. c. Containing EP $(133.3 \mu \mathrm{M}$ and different concentrations of AC (from inner to outer): AC (3.3, 10.0, 20.0, 26.6, 33.3, $40.0,50.0,66.6,83.3,100.0,116.6,133.3,150.0,166.6,183.3,200.0,216.6,233.3,250.0,266.6$, and 283.3).

$\left[\left(\mathrm{NH}_{3}\right)_{5} \mathrm{Ru}^{\mathrm{III}}-\mathrm{O}-\mathrm{Ru}^{\mathrm{IV}}\left(\mathrm{NH}_{3}\right)_{4}-\mathrm{O}-\mathrm{Ru}^{\mathrm{III}}\left(\mathrm{NH}_{3}\right)_{5}\right]^{6+} \longrightarrow$ $\left[\left(\mathrm{NH}_{3}\right)_{5} \mathrm{Ru}^{\mathrm{IV}}-\mathrm{O}-\mathrm{Ru}^{\mathrm{III}}\left(\mathrm{NH}_{3}\right)_{4}-\mathrm{O}-\mathrm{Ru}^{\mathrm{IV}}\left(\mathrm{NH}_{3}\right)_{5}\right]^{7+}+\mathrm{e}-$

(1)

An approximate estimate of the surface coverage of the electrode was made by adopting the method used by Sharp et $a l .{ }^{47}$ Therefore, the peak current must be related to the surface concentration of electroactive species, $\Gamma$, following Eq. (2):

$$
I_{\mathrm{P}}=\frac{n^{2} F^{2} \mathrm{~A} \Gamma v}{4 \mathrm{RT}}
$$

where $n$ represents the number of electrons involved in the reaction, $A$ is the geometric surface area of the electrode $\left.\left(0.0314 \mathrm{~cm}^{2}\right), \Gamma(\mathrm{mol} \mathrm{cm})^{-2}\right)$ the surface coverage, $v$ the scan rate, and $R, F$ and $T$ have their normal meanings. From the 
slope 0.214 of anodic peak currents vs. scan rate (Fig. 1b) the calculated surface concentration of RR in NF-RR-CNTs is $7.2 \times 10^{-9} \mathrm{~mol} \mathrm{~cm}^{-2}$ for $n=1$.

Differential pulse voltammetric studies of EP and AC

Figure 2 shows the DPVs of EP and AC $(126.6 \mu \mathrm{M}$ each) in 0.1M AABS with pH 5.5 for a bare GC electrode (BGC), NF-RR/GC, NF-CNTs/GC and NF-RR-CNTs/GC modified electrodes. The BGC electrode showed two slightly and broad oxidation peaks for EP and $\mathrm{AC}$ at 0.45 and $0.72 \mathrm{~V}$, respectively (Fig. 2a). The NF-RR/GC did not show any oxidation peaks for $\mathrm{EP}$ and $\mathrm{AC}$ in the potential range $-0.5-1.0 \mathrm{~V}$ (Fig. 2b). The NF-CNTs/GC show a broad peak for a binary mixture of EP and $\mathrm{AC}$ at potential of $0.75 \mathrm{~V}$ (Fig. 2c). This result showed that NF-CNTs/GC could not separate the oxidation peaks of EP and AC. The EP and AC were oxidized at 0.235 and $0.405 \mathrm{~V}$ in two well-defined DPV peaks with enhanced oxidation current response at the NF-RR-CNTs/GC electrode (Fig. 2d). Also, the peak at $-0.28 \mathrm{~V}$ for $\mathrm{Ru}{ }^{\mathrm{III}}-\mathrm{Ru}^{\mathrm{IV}}-\mathrm{Ru}^{\mathrm{III}} / \mathrm{Ru}^{\mathrm{IV}}-\mathrm{Ru}^{\mathrm{III}}-\mathrm{Ru}^{\mathrm{IV}}$ redox couple was decreased. Furthermore, the oxidation peaks of EP and AC were more stable at the NF-RR-CNTs/GC electrode in the subsequent cycles. The mechanism of this phenomenon can be written as follows:

$$
\begin{aligned}
& 2 \mathrm{Ru}^{\mathrm{III}}-\mathrm{Ru}^{\mathrm{IV}}-\mathrm{Ru}^{\mathrm{III}}-2 \mathrm{e} \longrightarrow 2 \mathrm{Ru}^{\mathrm{IV}}-\mathrm{Ru}^{\mathrm{III}}-\mathrm{Ru}^{\mathrm{IV}} \\
& 2 \mathrm{Ru}^{\mathrm{IV}}-\mathrm{Ru}^{\mathrm{III}}-\mathrm{Ru}^{\mathrm{IV}}+\underset{\mathrm{EPed}}{ }\left(\text { or } A C_{\mathrm{Red}}\right) \longrightarrow \\
& 2 \mathrm{Ru}^{\mathrm{III}}-\mathrm{Ru}^{\mathrm{IV}}-\mathrm{Ru}^{\mathrm{III}}+\mathrm{EP}_{\mathrm{Ox}}\left(\text { or } A C_{\text {Ox }}\right)
\end{aligned}
$$

These results showed that the electrooxidation of EP and AC can be catalyzed by $\mathrm{Ru}{ }^{\mathrm{III}}-\mathrm{Ru}^{\mathrm{IV}}-\mathrm{Ru}^{\mathrm{III}} / \mathrm{Ru}^{\mathrm{IV}}-\mathrm{Ru}^{\mathrm{III}}-\mathrm{Ru}^{\mathrm{IV}}$ couple as a mediator at the surface of the modified electrode.

The separation of oxidation peak potential of EP and AC was $170 \mathrm{mV}$ which was enough for the simultaneous determination of this binary mixture.

\section{$p H$ and interference studies for simultaneous determination of $E P$ and $A C$}

The effect of $\mathrm{pH}$ on the NF-RR-CNTs/GC signal was investigated by DPVs using $0.1 \mathrm{~mol} \mathrm{~L}^{-1}$ buffer solutions at $\mathrm{pH}$ levels ranging from 1.5 to 5.5. The results are shown in Fig. 3a. The results show that the peak current of EP increased with an increase in the solution $\mathrm{pH}$ until it reached 5.5. The peak current for AC slightly changed with an increase in the solution pH from 1.5 to 5.5. Based on Fig. 3a, the highest peak current was obtained at pH 5.5 for both compounds. It was observed that as the $\mathrm{pH}$ of the medium gradually increased, peak potentials for the oxidation of AC and EP shifted towards less positive values, showing that protons have taken part in their electrode processes. Out of these, the acetate buffer solution with $\mathrm{pH} 5.5$ gave the best response in terms of peak current and peak shape and negatively shifts, hence was chosen as the optimal $\mathrm{pH}$ for further studies. The plots of $E_{\mathrm{p}} v s . \mathrm{pH}$ for $\mathrm{EP}$ and $\mathrm{AC}$ in the working $\mathrm{pH}$ range were drawn and the $E_{\mathrm{p}}$ of both compounds show a linear relationship with $\mathrm{pH}$ of the buffer solution regarding following equations:

$$
\begin{aligned}
& E_{(\mathrm{p}, \mathrm{EP})}(\mathrm{mV})=0.555-0.057 \mathrm{pH} \quad\left(r^{2}=0.999\right) \\
& E_{(\mathrm{p}, \mathrm{AC})}(\mathrm{mV})=0.709-0.054 \mathrm{pH} \quad\left(r^{2}=0.998\right)
\end{aligned}
$$

Regarding the observed slopes of 0.057 and $0.054 \mathrm{mV} / \mathrm{pH}$ for $\mathrm{EP}$ and $\mathrm{AC}$ the values were close to the anticipated Nernstian value for a two-electron and two-proton electrochemical reaction. ${ }^{48}$ It can be concluded that an equal number of electrons
Table 1 Effect of interferences on determination of $50.0 \mu \mathrm{M}$ $\mathrm{AC}$ and $\mathrm{EP}$

\begin{tabular}{lcc}
\hline $\begin{array}{c}\text { Foreign } \\
\text { compound }\end{array}$ & $\begin{array}{c}\text { Foreign compound/ } \\
\text { AC and EP ratio }\end{array}$ & $\begin{array}{c}\text { Recovery, } \\
\%\end{array}$ \\
\hline phenylalanine & 300 & 98.2 \\
L-cysteine & 200 & 97.3 \\
L-Tyrosine & 300 & 96.0 \\
Metionine & 250 & 98.0 \\
Folic acid & 300 & 99.4 \\
Glucose & 400 & 98 \\
Atropine & 200 & 95.7 \\
Asparagine & 300 & 96.9 \\
Dopamine & 200 & 96.3 \\
ascorbic acid & 400 & 97.7 \\
Vitamin B6 & 450 & 98.7 \\
\hline
\end{tabular}

and protons are involved in the electrode reactions. At higher $\mathrm{pH}(\mathrm{pH}>5)$ using phosphate buffer, the anodic peak currents, the peak separation and repeatability for determination of EP and $\mathrm{AC}$ decreased. Also, at higher $\mathrm{pH}$ levels, electrode fouling increased.

In order to demonstrate the selectivity of the method for the simultaneous determination of $\mathrm{EP}$ and $\mathrm{AC}$ in $\mathrm{pH} 5.5$, the influence of potentially interfering substances on the determination of these compounds were investigated. In each experiment, the concentration of one species changed, while the concentrations of the other one were kept constant. The results are shown in Figs. 3b and 3c. It can be seen from Fig. 3b that peak current of EP increases with an increase in the concentration of $\mathrm{EP}$, while the peak current for the oxidation of $\mathrm{AC}$ remains constant. As can be seen (Fig. 3c), the voltammetric peak corresponding to the oxidation of $\mathrm{AC}$ was found to increase linearly in consonance with the increasing of the concentration of AC, whereas, the peak current for the oxidation of EP remained constant. Also, the influence of various foreign species on the determination of $50.0 \mu \mathrm{mol} \mathrm{L}^{-1} \mathrm{EP}$ and AC were investigated. The tolerance limit was taken as the maximum concentration of the foreign substances, which caused an approximately $\pm 5 \%$ relative error in the determination of compounds. The results of this investigation are summarized in Table 1.

\section{Chronoamperometric studies}

Chronoamperometric measurements of EP and AC at NF-RRCNTs/GC were also studied by setting the working electrode potential at 0.3 and $0.45 \mathrm{~V} v s$. SCE for the various concentrations of $\mathrm{EP}$ and $\mathrm{AC}$ in AABS ( $\mathrm{pH}$ 5.5) for determination of the diffusion coefficient (D) of EP and AC. For an electroactive with a diffusion coefficient of $\mathrm{D}$, the current for the electrochemical reaction with a mass transport limited rate is described by the Cottrell equation. ${ }^{48}$

$$
I=n F A D^{1 / 2} C_{\mathrm{b}} \pi^{-1 / 2} t^{-1 / 2}
$$

Under diffusion control, a plot of $I v s . t^{-1 / 2}$ for EP will be linear, and the slope of the linear region of the Cottrell's plot can be used to estimate the $D$ for $\mathrm{EP}\left(D_{\mathrm{EP}}\right)$ and $\mathrm{AC}\left(D_{\mathrm{AC}}\right)$. The value of $D_{\mathrm{EP}}$ and $D_{\mathrm{AC}}$ were found to be $2.74 \pm 0.05 \times 10^{-5}$ and $1.95 \pm 0.07$ $\times 10^{-5} \mathrm{~cm}^{2} \mathrm{~s}^{-1}$, respectively.

\section{Simultaneous determination of EP and AC}

The simultaneous determination of $\mathrm{EP}$ and $\mathrm{AC}$ was investigated by synchronously changing the concentrations of EP and $\mathrm{AC}$ 
and recording the DPV. As shown in Fig. 4a, the DPV curves showed two well-distinguished oxidation peaks. Voltammograms clearly show that the plot of the peak current $v s$. EP concentration is composed of two linear segments with different slopes (Fig. 4b).

In the case of $\mathrm{EP}$ and $\mathrm{AC}$, electrocatalytic peak currents of $\mathrm{EP}$ and $\mathrm{AC}$ oxidation at the surface of GC/CNTs-RR-NF were linearly dependent on the $\mathrm{EP}$ and $\mathrm{AC}$ concentrations; over the range of $0.3-333.3 \mu \mathrm{M}$ with detection limit 0.04 and $0.06 \mu \mathrm{M}$ for $\mathrm{EP}$ and $\mathrm{AC}$, respectively. For seven successive determinations of $60.0 \mu \mathrm{M}$ of EP and $\mathrm{AC}$, the relative standard deviations were 1.9 and $2.2 \%$, respectively. The results of the calibration characteristics at NF-RR-CNTs/GC electrode are presented in Table 2. These results show that the proposed electrode can be used effectively for the simultaneous determination of EP and
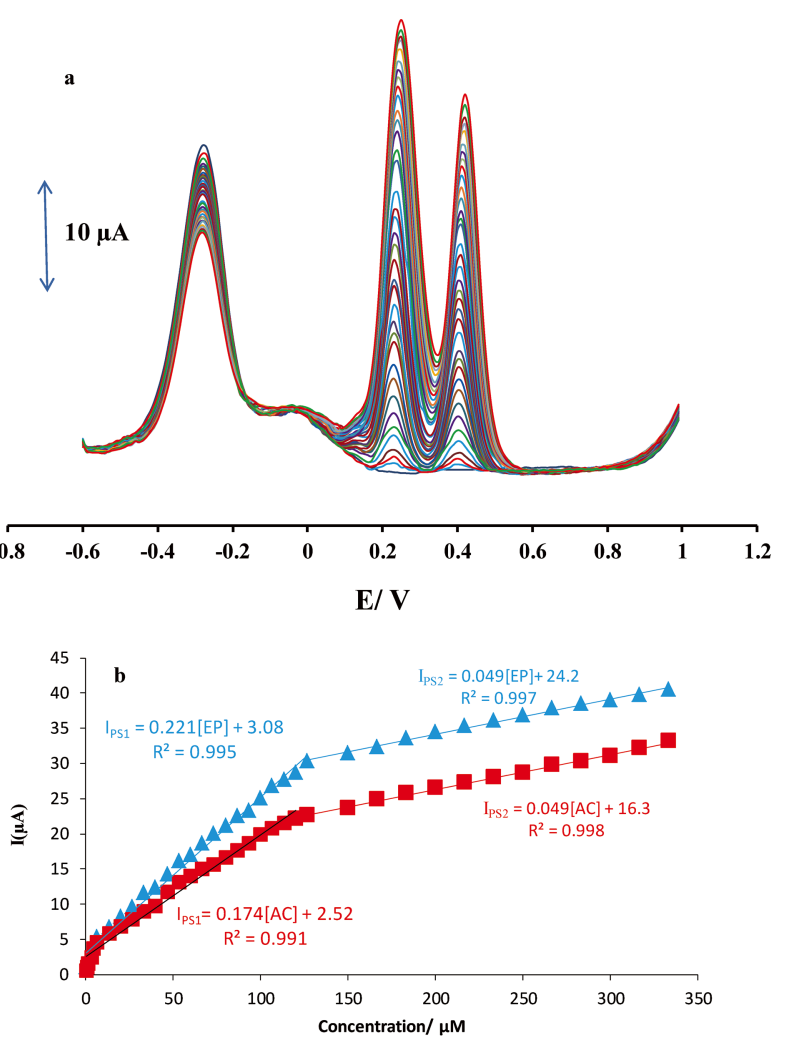

Fig. 4 a. DPV of the mixtures of EP and AC at the NF-RR-CNTs/ GC electrode in AABS ( $\mathrm{pH} 5.5$ ) at the scan rate of $100 \mathrm{mV} \mathrm{s}^{-1}$. Concentrations from inner to outer of curves: $\mathrm{EP}$ and $\mathrm{AC}(0.0,0.3$, $0.45,1.3,0.45,3.3,6.6,13.3,20.0,26.6,33.3,40.0,46.6,53.3,60.0$, 66.6, 73.3,80.0, 86.6, 93.3, 100.0, 106.6, 133.3, 120.0, 126.6, 150.0, 166.6, 183.3, 200.0, 216.6, 233.3, 250.0, 266.6, 283.3, 300.0, 316.6, 333.3). Insets: b. Plots of I vs. concentrations.
AC.

The stability of the NF-RR-CNTs/GC electrode was studied by measuring the electrocatalytic peak currents, in repetitive potential scan cycles on different days. The electrode did not show a significant change in the peak currents of EP and AC for more than seven months; such results could prove the stability of the modified electrode. Also, the repeatability of the modified electrode was checked for simultaneous determination of EP and AC. Relative standard deviations (\% RSD) for five determinations of EP and AC (50 $\mu \mathrm{M}$ each) using DPV were 1.37 and $1.23 \%$, respectively.

\section{Real sample analysis}

$\mathrm{EP}$ and $\mathrm{AC}$ were measured in real samples in order to demonstrate the capability of the modified electrode for the determination of EP and AC in real samples. Human serum and urine samples and AC tablets were selected as real samples for analysis by the proposed method using the standard addition method. In order to avoid the interferences of the real samples from real sample matrices and to fit the results into the linear range of $\mathrm{EP}$ and $\mathrm{AC}$, only $5 \mathrm{~mL}$ of each urine or serum sample was added to the electrochemical cell containing $5 \mathrm{~mL}$ of the buffer solution and measurement was performed. For determination of AC in tablet samples, 10 tablets were accurately weighed and finely powdered. Appropriate amounts of the powdered samples for preparation of $20 \mu \mathrm{M}$ solution was dissolved in 0.1 M AABS $(\mathrm{pH}=5.5)$ then DPVs were applied for the determinations in result and various spiked solutions of $\mathrm{AC}$ at NF-RR-CNTs/GC. The results are presented in Table 3. In order to evaluate the accuracy of the method, the diluted samples mentioned above were spiked with known amounts of standard EP and AC solutions; the recoveries were found to be satisfactory (95.6 and 99.2\%) as shown in Table 3. The recovery ratio indicates that the determination of $\mathrm{EP}$ and $\mathrm{AC}$ using the proposed electrode is effective and can be applied for the detection of EP and AC in real samples.

Table 3 Determination of EP and AC in tablets, human serum and urine samples using NF-RR-CNTs/GC $(n=5)$

\begin{tabular}{lcccccc}
\hline Sample & Analyte & $\begin{array}{c}\text { Detected/ } \\
\mu \mathrm{M}^{\mathrm{a}}\end{array}$ & $\begin{array}{c}\text { Added/ } \\
\mu \mathrm{M}\end{array}$ & $\begin{array}{c}\text { Found/ } \\
\mu \mathrm{M}^{\mathrm{a}}\end{array}$ & $\begin{array}{c}\text { Recovery, } \\
\%\end{array}$ & $\begin{array}{c}\mathrm{RSD}, \\
\%\end{array}$ \\
\hline \multirow{2}{*}{ Tablet } & $\mathrm{AC}$ & $19.4 \pm 0.9$ & 20.0 & $38.3 \pm 1.1$ & 97.2 & 1.47 \\
& & & 50.0 & $69.8 \pm 2.4$ & 99.2 & 1.07 \\
\multirow{4}{*}{ Serum } & $\mathrm{AC}$ & $\mathrm{ND}^{\mathrm{b}}$ & 30.0 & $28.6 \pm 1.8$ & 95.4 & 1.76 \\
& $\mathrm{EP}$ & $\mathrm{ND}^{\mathrm{b}}$ & 50.0 & $47.8 \pm 2.3$ & 95.6 & 1.87 \\
Urine & $\mathrm{AC}$ & $\mathrm{ND}^{\mathrm{b}}$ & 30.0 & $29.2 \pm 2.0$ & 97.4 & 1.90 \\
& $\mathrm{EP}$ & $\mathrm{ND}^{\mathrm{b}}$ & 50.0 & $48.4 \pm 2.5$ & 96.8 & 2.11 \\
\hline
\end{tabular}

a. Mean \pm standard deviation for $n=5$.

b. Not detected.

Table 2 Analytical characteristics of the method

\begin{tabular}{|c|c|c|c|c|c|}
\hline \multirow{2}{*}{ Analyte } & \multicolumn{2}{|c|}{ Linear dynamic range $/ \mu \mathrm{M}$} & \multicolumn{2}{|c|}{ Regression equation and Correlation coefficient } & \multirow{2}{*}{$\begin{array}{l}\text { Detection } \\
\text { limit/ } \mu \mathrm{M}\end{array}$} \\
\hline & (first segment) & (second segment) & (first segment) & (second segment) & \\
\hline EP & $0.3-126.6$ & $126.6-333.3$ & $\begin{array}{l}y=0.221 x+3.07 \\
r=0.995\end{array}$ & $\begin{array}{l}y=0.049 x+24.23 \\
r=0.9966\end{array}$ & 0.04 \\
\hline $\mathrm{AC}$ & $0.3-120.0$ & $120.0-333.3$ & $\begin{array}{l}y=0.174 x+2.52 \\
r=0.9914\end{array}$ & $\begin{array}{l}y=0.0498 x+16.32 \\
r=0.998\end{array}$ & 0.06 \\
\hline
\end{tabular}


Table 4 Comparison of the proposed method with other electroanalytical methods with GC/CNTs-RR-NF electrodes for the simultaneous determination of $\mathrm{EP}$ and $\mathrm{AC}$

\begin{tabular}{|c|c|c|c|c|c|c|}
\hline Electrode & Modifier & $\mathrm{pH}$ & Analyte & Linear range $/ \mu \mathrm{M}$ & Detection limit/ $\mu \mathrm{M}$ & Ref. \\
\hline Graphite electrode & Functionalized MWCNTs & 7.0 & $\mathrm{AC}$ & $25.0-4.0 \times 10^{2}$ & 0.5 & 15 \\
\hline Glassy carbon & Graphene & 8.0 & $\mathrm{AC}$ & $1.0-1.0 \times 10^{2}$ & 0.3 & 16 \\
\hline Glassy carbon & $\mathrm{CNT}$ & & $\mathrm{AC}$ & $3.0-3.0 \times 10^{2}$ & 0.6 & 50 \\
\hline Carbon paste & $\mathrm{TiO}_{2}$ nanoparticles & 8.0 & EP & $1.0-6.0 \times 10^{2}$ & 0.2 & 49 \\
\hline Carbon paste & Iron phthalocyanine & 4.0 & $\mathrm{AC}$ & $1.0-1.3 \times 10^{2}$ & 0.5 & 23 \\
\hline Graphite electrode & Polyrutin & 4.0 & EP & $3.0-90.0$ & 0.8 & 40 \\
\hline Glassy carbon & Poly(eriochrome Black T) & 3.5 & EP & $2.5-51.0$ & 0.3 & 39 \\
\hline Carbon nanotube paste & Ferrocenedicarboxylic acid & 5.0 & EP & $5.0 \times 10^{-2}-4.5 \times 10^{2}$ & $3.5 \times 10^{-2}$ & 51 \\
\hline \multirow[t]{2}{*}{ Glassy carbon } & NF-RR-CNTs & 5.5 & $\mathrm{AC}$ & $0.3-333.3$ & $4.0 \times 10^{-2}$ & \\
\hline & & & EP & $0.3-333.3$ & $6.0 \times 10^{-2}$ & This work \\
\hline
\end{tabular}

\section{Conclusions}

The present study demonstrates for the first time the construction of a NF-RR-CNTs/GC and its application for the simultaneous determination of EP and AC. A well-defined peak and a significant increase of peak current were observed at the NF-RR-CNTs/GC, clearly demonstrating that RR could be used as an efficient modifier to enhance the kinetics of the electrochemical process of EP and AC. The optimization of the experimental conditions for differential pulse voltammetry yielded a detection limit for EP of $0.04 \mu \mathrm{M}$ and 0.06 for $\mathrm{AC}$ which are better than those described in the literature (Table 4).

\section{References}

1. L. Jackson, F. L. R. Williams, A. Burchell, M. W. H. Coughtrie, and R. Hume, J. Clin. Endocrinol. Metab., 2004, 89,6251 .

2. J. Bergquist, A. Sciubisz, A. Kaczor, and J. Silberring, $J$. Neurosci. Methods., 2002, 113, 1.

3. C.-W. Hsu and M.-C. Yang, Sens. Actuators, B, 2008, 134, 680.

4. S. Shahrokhian, M. Ghalkhani, and M. K. Amini, Sens. Actuators, B, 2009, 137, 669.

5. C. G. Amorim, A. N. Araujo, and M. C. B. S. M. Montenegro, Talanta, 2007, 72, 1255.

6. T. R. Ling, Y. Z. Syu, Y. C. Tasi, T. C. Chou, and C. C. Liu, Biosens. Bioelectron., 2005, 21, 901.

7. V. Carrera, E. Sabater, E. Vilanova, and M. A. Sogorb, J. Chromatogr. B, 2007, 847, 88.

8. G. Zhang, Y. Zhang, C. Ji, T. McDonald, J. Walton, E. A. Groeber, R. C. Steenwyk, and Z. Lin, J. Chromatogr. B: Anal. Technol. Biomed. Life Sci., 2012, 895 - 896, 186.

9. S. Wei, G. Song, and J. M. Li, J. Chromatogr. A, 2005, 1098, 166.

10. Y. Zhao, S. Zhao, J. Huang, and F. Ye, Talanta, 2011, 85, 2650.

11. A. V. Bulatov, A. V. Petrova, A. B. Vishnikin, A. L. Moskvin, and L. N. Moskvin, Talanta, 2012, 96, 62.

12. T. Li, Z. Wang, H. Xie, and Z. Fu, J. Chromatogr. B: Anal. Technol. Biomed. Life Sci., 2012, 911, 1.

13. P. Canizares and L. de Castro, Anal. Chim. Acta, 1995, 317, 335.

14. P. Solich, C. K. Polydorou, M. A. Koupparis, and C. E. Efstathiou, J. Pharm. Biomed. Anal., 2000, 22, 781.

15. E. V. Efremov, F. Ariese, and C. Gooijer, Anal. Chim. Acta,
2008, 606, 119.

16. W. Ren, H. Q. Luo, and N. B. Li, Biosens. Bioelectron., 2006, 21, 1086.

17. Y. Hong, S. Yuanyuan, L. Xinhua, T. Yuhai, L. Ailin, L. Guangwen, L. Wei, and Z. Shaobo, Anal. Sci., 2007, 23, 677.

18. G. P. Jin, Q. Z. Chen, Y. F. Ding, and J. B. He, Electrochim. Acta, 2007, 52, 2535.

19. Y. Wang and Z. Z. Chen, Colloids Surf., B, 2009, 74, 322.

20. J. Huo, J. Li, and Q. Li, Mater. Sci. Eng., 2013, 33, 507.

21. H. Beitollahi, M. Mazloum Ardakani, B. Ganjipour, and H. Naeimi, Biosens. Bioelectron., 2008, 24, 362.

22. M. Mazloum-Ardakani, H. Beitollahi, M. K. Amini, B.-F. Mirjalili, and F. Mirkhalaf, J. Electroanal. Chem., 2011, 651, 243.

23. W. Y. Su and S. H. Cheng, Electroanalysis, 2010, 22, 707.

24. A. Kratz, M. Ferraro, P. M. Sluss, and K. B. Lewandrowski, N. Engl. J. Med., 2004, 351, 1548.

25. N. W. Tietz, "Clinical Guide to Laboratory Tests", 3rd ed., 1995, Saunders.

26. M. Boopathi, M. S. Won, and Y. B. Shim, Anal. Chim. Acta, 2004, 512, 191.

27. C. Nebot, S. W. Gibb, and K. G. Boyd, Anal. Chim. Acta, 2007, 598, 87.

28. K. R. Ing-Lorenzini, J. A. Desmeules, M. Besson, J. Veuthey, P. Dayer, and Y. Daali, J. Chromatogr. A, 2009, $1216,3851$.

29. A. B. Moreira, H. P. M. Oliveira, T. D. Z. Atvars, L. L. T. Dias, G. O. Neto, E. A. G. Zagatto, and L. T. Kubota, Anal. Chim. Acta, 2005, 539, 257.

30. M. R. Khoshayand, H. Abdollahi, M. Shariatpanahi, A. Saadatfard, and A. Mohammadi, Spectrochim. Acta, Part A, 2008, 70, 491.

31. H. Filik, D. Aksu, R. Apak, I. Şener, and E. Kılıç, Sens. Actuators, B, 2009, 136, 105.

32. J. A. M. Pulgarin and L. F. G. Bermejo, Anal. Chim. Acta, 1996, 333, 59.

33. W. Ruengsitagoon, S. Liawruangrath, and A. Townshend, Talanta, 2006, 69, 976.

34. H. Razmi and E. Habibi, Electrochim. Acta, 2010, 55, 8731 .

35. R. Manjunatha, D. H. Nagaraju, G. S. Suresh, J. S. Melo, S. F. D'Souza, and T. V. Venkatesha, Electrochim. Acta, 2011, 56,6619 .

36. C. W. Kung, C. Y. Lin, R. Vittal, and K. C. Ho, Sens. Actuators, B, 2013, 182, 429.

37. M. P. Ngoc Bui, C. A. Li, K. N. Han, X. H. Pham, and G. H. Seong, Sens. Actuators, B, 2012, 174, 318.

38. M. Zheng, F. Gao, Q. Wang, X. Cai, S. Jiang, L. Huang, 
and F. Gao, Mater. Sci. Eng., 2013, 33, 1514.

39. S. A. Kumar, C. F. Tang, and S. M. Chen, Talanta, 2008, 76, 997.

40. S. F. Wang, F. Xie, and R. F. Hu, Sens. Actuators, B, 2007 123, 495 .

41. M. Boopathi, M. S. Won, and Y. B. Shim, Anal. Chim. Acta, 2004, 512, 191.

42. F. Vincent and M. A. Duncton, Curr. Top. Med. Chem., 2011, 11, 2216.

43. L. X. A. Tripathy, D. A. Pasek, and G. Meissner, Ann. N. Y. Acad. Sci., 1998, 853, 130.

44. M. F. S. Teixeira, M. F. Bergamini, C. M. P. Marques, and N. Bocchi, Talanta, 2004, 63, 1083.

45. V. Selvaraj, M. Vinoba, and M. Alagar, J. Colloid Interface Sci., 2008, 322, 537.
46. M. Yagi, S. Tokita, K. Nagoshi, I. Ogino, and M. Kaneko, J. Chem. Soc., Faraday Trans., 1996, 92, 2457.

47. M. Sharp, M. Petersson, and K. Edstrom, J. Electroanal. Chem., 1979, 95, 123.

48. A. J. Bard and L. R. Faulkner, "Electrochemical Methods: Fundamentals and Applications", 2nd ed., 2001, Wiley, New York.

49. M. Mazloum-Ardakani, H. Beitollahi, M. A. Sheikh Mohseni, A. Benvidi, H. Naeimi, M. Nejati-Barzoki, and N. Taghavinia, Colloids Surf., B, 2010, 76, 82.

50. Z. A. Alothmana, N. Bukhari, S. M. Wabaidur, and S. Haider, Sens. Actuators, B, 2010, 146, 314.

51. H. Yaghoubian, H. Beitollah, V. Soltani-Nejad, A. Mohadesi, D. Afzali, H. Zamani, and S. Roodsaz, Int. J. Electrochem. Sci., 2011, 6, 1307. 